\title{
Perceived Innovativeness and Competitiveness of Early-Stage Entrepreneurs
}

\section{Polona Tominc}

Faculty of Economics and Business, University of Maribor, Maribor, Slovenia polona.tominc@um.si
CroEconSur

Vol. 21

No. 1

June 2019

pp. 87-108

Received: September 18, 2018 Accepted: May 15, 2019

Research Article

doi:10.15179/ces.21.1.3

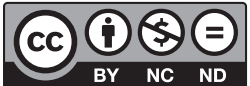

\section{Abstract}

In our paper we study the perceived innovativeness of entrepreneurs, i.e. owners and managers of start-ups in three neighboring countries-Slovenia, Croatia, and Hungary-based on the research framework and adult population surveys within the Global Entrepreneurship Monitor (GEM) research cycles in 2016 and 2017. Innovativeness is studied as a multidimensional process: from the perspective of technologies, product innovations, and competition. Our results show that higher innovativeness of products/services produced by early-stage entrepreneurs is associated with higher levels of technological innovativeness and with lower levels of market competition. Neither gender nor age shows a statistically significant relationship with the product/service innovativeness of early-stage entrepreneurs. The results also show that the specific institutional 
environment in each country does not moderate the relationships between the innovativeness of products/services on one hand, and technological and market competition viewpoints of innovativeness, on the other.

Keywords: innovativeness, early-stage entrepreneurs, Global Entrepreneurship Monitor

JEL classification: L26, O31

\section{Introduction}

The Global Entrepreneurship Monitor (GEM) research program was developed with the aim of providing harmonized data for the research of different entrepreneurship forms in different economies around the globe, which are at very different developmental levels. GEM has its beginnings in 1997. The first adult population survey, which represents the main GEM data source, was carried out in 1999, with ten countries participating. To date, GEM has evolved into a consortium in which a large number of countries participate and represents a unique global research project, unprecedented in entrepreneurial research. Slovenia has been participating in this project since 2002. The basic mission of GEM is to create reliable international data on entrepreneurial activity and to inform the public about them as widely as possible. The methodology of the study and the process of data harmonization across participating countries are described in detail in Reynolds et al. (2005) and in the GEM Manual (2017).

The GEM framework is focused especially on the analysis of early-stage entrepreneurship, which often is not entirely aligned with the objectives pursued by economic policy makers, who mainly focus on a macroeconomic aspect; this is the aspect that notices entrepreneurship only when it manifests itself in a successful, growing company and contributes to the increase in gross domestic product (Rebernik et al., 2016). Within this aspect, it is often forgotten that it is precisely the start of the entrepreneurial process - the enthusiasm for the 
constant formation of new, innovative ideas and entrepreneurial ambitions of individuals - that restores the economic structure (although this does not apply to all forms of entrepreneurship, as there are many forms of speculative and destructive entrepreneurship; Baumol, 1993; Klein, 2007).

Entrepreneurship, as explored in the framework of the GEM research, is considered as the way in which individuals seek, create, or exploit business opportunities and forms an integral part of the socioeconomic process of "creative destruction" (Schumpeter, 1934), on which economic and social development is based. Entrepreneurship is based on the central human ability to think, explore, and search for better ways to enable the desired level of income; in short, it is entrepreneurial and constitutive. Therefore, the study of entrepreneurship within the framework of GEM is primarily the study of the fundamental driving force, that is, the individuals and their ambitions, innovativeness, and abilities, and the study of all factors that may influence the individual's entrepreneurial activity (Rebernik et al., 2018). An additional reason for an individual level research approach is that in small and medium sized companies, that represent the majority in the economic structure of most economies in the world, the importance of an owner's or manager's role in the company's process of growth is likely to be relatively greater than in a large firm.

In our paper we study the perceived innovativeness of entrepreneurs, i.e. owners and managers of start-ups. Since our analysis focuses on entrepreneurs in the early-stages of entrepreneurship, the innovation of their enterprises (from the perspective of technologies, product innovations, and competition, as we describe later in the paper) can be analyzed only on the basis of the subjective assessments of innovativeness as perceived by the entrepreneurs themselves.

The present research is focused on the innovativeness of early-stage entrepreneurial activity. Previous research suggests that innovativeness is an important driver of a company's growth (Teece, 2007; Coad \& Rao, 2008; Koellinger, 2008; Zimmermann, 2009; Falk, 2015). Growing companies represent a small part of the entrepreneurial population in all world economies (Autio, 2007), but they 
are of utmost importance for the development of national economies, especially because of their contribution to the creation of new jobs. Past research also emphasizes that there is a lack of empirical evidence on growth influencers and the interrelated impact of individual factors and the entrepreneurship ecosystem in the process of business growth (Acs, Estrin, Mickiewicz, \& Szerb, 2018; Singer, Šarlija, Pfeifer, \& Oberman Peterka, 2017; Lafuente, Acs, \& Szerb, 2018).

The innovation stance of the companies is measured in the GEM adult population survey through the prism of the introduction of products and/or services that are new to potential customers - this aspect is very often accompanied by the competitive position of a company, which refers to the number of companies/ providers that offer similar/identical products or services on the market (GERA, 2019). The third aspect of the innovative characteristic is the novelty of technology, namely, the innovativeness of the technologies used by companies in their business process (Koellinger, 2008; Šarlija \& Pfeifer, 2015).

Perceived innovativeness of services/products produced, as well as the perceived competitive position of businesses and innovativeness of technologies used, are therefore key indicators with which GEM measures and explores innovativeness at all stages of the entrepreneurial activity cycle, from new to established entrepreneurs. The main purpose of the present paper is to explore the relationships between the above-mentioned perceived dimensions of innovation and the demographic characteristics of individuals - age and gender of early-stage entrepreneurs-with the objective to identify characteristics of entrepreneurs and their businesses that may be related to the innovative stance of their companies. This may be important for economic policy makers, with the purpose of identifying entrepreneurs that are most likely to achieve a "market breakthrough" with their innovative approach and to create, consequently, employment growth.

Our research is focused on three countries that have shared a common socioeconomic environment for decades and have many common features, namely Slovenia, Croatia, and Hungary. The differences between the countries were not 
at the outset of our research; we were interested in the innovativeness of the earlystage entrepreneurial activity and the factors associated with it in the combined geographical region of these three states. Data for 2016 were used for Hungary, while data from the 2017 GEM Adult Population Survey (APS) were used for Croatia and Slovenia.

\section{Literature Review and Research Hypotheses}

The contribution of entrepreneurship to economic growth has been emphasized as the most important feature of the "quality" of entrepreneurial activity (Baum, Locke, \& Smith, 2001; Morris, Webb, \& Bryant, 2011). Since the work of Birch (1979) about the job generation process, high-growth companies (fast-growing companies) have been in the focus of both academic research and economic policy objectives, with constant questions on how to ensure the most efficient way for rapid growth of companies, their employment, and contribution to gross domestic product. A comprehensive theoretical approach to explain the growth of enterprises does not yet exist, but the growth of an enterprise is generally deemed an expression of successful action enabling it to achieve competitive advantages over its competitors (Autio, 2007; Zimmermann, 2017).

Past entrepreneurship research studies have highlighted the importance of innovations and innovativeness of companies as important fuel for business growth (Teece, 2007; Coad \& Rao, 2008; Koellinger, 2008; Zimmermann, 2009; Falk, 2015). Innovativeness is most frequently viewed as a measure of the degree of newness of an innovation. For the purposes of this research, we will focus on the definition of innovativeness that is used in GEM, which is in line with above-presented aspects. Therefore, innovativeness is analyzed from three different points of view: newness of products and/or services produced, technological point of view, and competitors' point of view (Koellinger, 2008; Šarlija \& Pfeifer, 2015; Rebernik et al., 2016). Entrepreneurs are innovative from the aspect of newness of their products/services, if their enterprises offer products/ 
services that are new to all or at least to some of the (potential) consumers; from the technological point of view, if they use new technologies that are available on the market less than five years; and from the competition's point of view, if they operate on markets with no competing businesses. Common to all three aspects of innovativeness is novelty. This is in line with the findings of Garcia and Calantone (2002) who have pointed out that although there are many different aspects of innovativeness, these aspects have a common point, which is related to market. We emphasize that this approach to identifying a company's innovation level is quite different from the concept used for innovativeness in terms of patents, research and development expenditure, and the like. The fact is that it is a perceived innovativeness, which can often be greatly determined by the environment in which the entrepreneurs are operating. In a more developed economic environment, the perception of innovation is, of course, quite different than in a less economically developed environment (Koellinger, 2008; GERA, 2018). As the research is based on entrepreneurs' perceptions regarding innovativeness, this limits a more in-depth distinction between product and process innovations (Hullova, Trott, \& Simms, 2016) of entrepreneurial endeavors.

The following hypotheses are formed:

H1: Higher innovativeness of products/services produced by early-stage entrepreneurs is associated with higher levels of technological innovativeness.

H2: Higher innovativeness of products/services produced by early-stage entrepreneurs is associated with lower levels of market competition.

The demographic characteristics of entrepreneurs (in this research we focus on gender and age of early-stage entrepreneurs) may have an impact on the characteristics and performance of the companies that they control, i.e. own and/or manage (Zimmermann, 2017). Some past research studies have shown that gender has an important role in entrepreneurial activity; to be precise, some studies have revealed that entrepreneurship, or entry to entrepreneurship, is 
a “young man's game" (Arenius \& Minniti, 2005). A similar conclusion can be drawn from the results of research on established companies, since in most countries in the world men are more likely to be entrepreneurially active than women (GERA, 2018; Rebernik et al., 2018). Roper and Scott (2009) found that women may face or perceive greater barriers in start-up phases, but at the same time, they did not find any evidence that this is likely to have a significant effect on the differences in start-up activities between women and men. There is also no doubt about the importance of women entrepreneurs in the economic development of a country, with regard to their contribution to job creation and economic growth (Tominc \& Rebernik, 2006), but some gender-specific obstacles regarding the innovative aspects of entrepreneurial activity of earlystage entrepreneurs may exist. For example, despite a similar average level of education achieved by women and men, women are often engaged in areas that are less suitable for entrepreneurship or have lower "innovative charge" (such as the field of services, care, etc.). Also, a frequent obstacle in implementing ambitious innovation activities is financing, and prior studies have suggested that men can obtain on average more generous external financing than women (Alsos, Isaksen, \& Ljunggren, 2006). For example, Brush, Carter, Gatewood, \& Hart (2004) have indicated that male-owned firms access formal and informal venture capital investments better than women-owned firms. This may lead to circumstances that favor men-owned/managed enterprises and enable them to grow more rapidly, supporting Delmar and Holmquist's (2004) findings that the growth rates of enterprises owned and/or managed by women are usually lower than those of enterprises owned and/or managed by men.

Research results regarding age show that young entrepreneurs lead innovative high-growth enterprises-entrepreneurs below the age of 40 are much more likely to be managing an innovative growth enterprise (Zimmermann, 2017). Age may also represent an important obstacle that is likely to reduce funding opportunities, although the role of age in financing and growth is vague. Some studies have identified a declining tendency to invest as entrepreneurial age rises 
(Romano, Tanewski, \& Smyrnios, 2001), while in other studies the entrepreneur's age was found to enhance capital acquisition and improve the ease of obtaining resources (Neeley \& Van Auken, 2010).

The following two hypotheses are formed:

H3: Higher levels of innovativeness of products/services produced are observed in male early-stage entrepreneurs as compared to female ones.

H4: Higher levels of innovativeness of products/services produced are observed in younger early-stage entrepreneurs as compared to older ones.

\section{Methodology}

As already mentioned, early-stage entrepreneurial activity is the basic metric within the GEM research and it refers to the share of the population, aged 18 to 64 years, that comprises either nascent entrepreneurs (people actively involved in setting up a business they will own or co-own; the business has not paid wages or other compensations to the owners for more than 3 months) or ownermanagers of new businesses (owner-managers of new businesses that have paid salaries or other compensations to the owners for more than 3 but not more than 42 months).

The GEM adult population survey is carried out with the help of a developed GEM questionnaire, which is the same in all participating countries and translated into national languages. The methodology of data collection and coding is established and uniform for all participating countries, which ensures the comparability of collected databases and a robust and meaningful in-depth analysis within a given economy as well as comparative analysis among the participating countries. The research methodology and data harmonization process are described in detail in Reynolds et al. (2005) and in the GEM Manual (2017). 
Definitions of variables:

- Innovativeness:

- Early-stage entrepreneurs are innovative from the aspect of newness of their products/services if their enterprises offer products/services that are new to all or to some potential consumers (dichotomous $0-1$ variable).

- Early-stage entrepreneurs are innovative from the technological point of view if they use technologies that are available on the market less than five years (dichotomous $0-1$ variable).

- Early-stage entrepreneurs are innovative from the competition's point of view if they operate on markets with no competing businesses (dichotomous $0-1$ variable).

- Control demographic variables are gender (dichotomous variable 0 - men and 1 - women) and age of an entrepreneur (in years).

- Country dummy variables.

The combined data set of the three countries was formed-the sample characteristics are provided in Table 1 .

Table 1: Sample Characteristics

\begin{tabular}{|c|c|c|c|}
\hline & Hungary & Croatia & Slovenia \\
\hline Sample size (n) & 2011 & 2000 & 2005 \\
\hline Share of early-stage entrepreneurs & $7.8 \%$ & $8.8 \%$ & $5.4 \%$ \\
\hline $\begin{array}{l}\text { Share of early-stage entrepreneurs that offer } \\
\text { products/services that are new to the majority or } \\
\text { all of the potential customers }\end{array}$ & $31.4 \%$ & $29.0 \%$ & $49.1 \%$ \\
\hline $\begin{array}{l}\text { Share of early-stage entrepreneurs using the latest } \\
\text { technologies }\end{array}$ & $21.8 \%$ & $58 \%$ & $38.9 \%$ \\
\hline $\begin{array}{l}\text { Share of early-stage entrepreneurs that operate on } \\
\text { markets with no competing businesses }\end{array}$ & $11.5 \%$ & $9.1 \%$ & $15.7 \%$ \\
\hline$\%$ of women among early-stage entrepreneurs & $31.0 \%$ & $38.1 \%$ & $30.6 \%$ \\
\hline $\begin{array}{l}\text { Age - mean value } \\
\text { Standard deviation }\end{array}$ & $\begin{array}{l}38.03 \text { years } \\
\mathrm{SD}=11.1\end{array}$ & $\begin{array}{l}38.37 \text { years } \\
\mathrm{SD}=11.5\end{array}$ & $\begin{array}{l}38.21 \text { years } \\
\mathrm{SD}=11.6\end{array}$ \\
\hline
\end{tabular}

Source: Author's systematization. 
To test hypotheses $\mathrm{H} 1-\mathrm{H} 4$, logistic regression was used. The logistic regression method allows one to predict a discrete outcome, in our case the innovativeness regarding the novelty of products/services produced by the earlystage entrepreneurs, from a set of variables, that may be continuous, discrete, dichotomous, or a mix. In our case this set consists of four variables: perceived novelty of technologies used, perceived competition, gender, and age; we included a country dummy variable, as well. Although the logistic regression answers the same questions as other methods for classification (for example, discriminant analysis), it is much more flexible regarding assumptions than any other multivariate method: unlike discriminant analysis, logistic regression has no assumptions about the distribution of the predictor variables, and predictor variables do not have to be normally distributed and linearly related to the dependent (grouping) variable, or of equal variance within each group (Tabachnick \& Fidell, 2013). Maximum likelihood estimations were used to estimate the coefficients of the logistic regression function, which denote changes in the log-odds of the independent variable. The goodness of fit of the model was assessed using Model $\chi^{2}$, the rate of correct classifications, and the Nagelkerke $\mathrm{R}^{2}$. In order to test whether the inclusion of predictor variables led to statistically significant improvements of the model, we used Blok $\chi^{2}$. In order to test the significance of the regression coefficient, we used the Wald test. The 0.05 (twotailed) significance level was used.

\section{Country Context}

Slovenia, Croatia, and Hungary are three neighboring countries that share decades of common history within the Austrian-Hungarian Monarchy before the Second World War; they also share almost five decades of socialism and a common communist history. Slovenia and Croatia were also parts of the same state (Yugoslavia) for seven decades. This means that in the past the countries had many similar systems within the framework of economic policy and 
characteristics that, after the breakup of socialism, influenced the formation of the entrepreneurial spirit of the economies.

Table 2: Comparison of Slovenia, Croatia, and Hungary, Selected Economic Indicators

\begin{tabular}{|c|c|c|c|}
\hline Main economic indicators & Slovenia & Croatia & Hungary \\
\hline Real GDP growth ${ }^{2}$ & $4.0 \%$ & $2.8 \%$ & $3.8 \%$ \\
\hline GDP per capita (USD) ${ }^{1}$ & $21,320.2$ & $12,095.5$ & $12,778.3$ \\
\hline GDP per capita $(P P P)^{4}$ & $36,570.0$ & $25,810.0$ & $31,370.0$ \\
\hline Consumer price inflation ${ }^{2}$ & $1.7 \%$ & $1.5 \%$ & $2.7 \%$ \\
\hline Unemployment rate ${ }^{2}$ & $5.9 \%$ & $12.0 \%$ & $3.8 \%$ \\
\hline Total population (millions) ${ }^{1}$ & 2.1 & 4.2 & 9.8 \\
\hline Total labor force ${ }^{3}$ & $56 \%$ & $51 \%$ & $56 \%$ \\
\hline Population $15-64^{3}$ & $1,363,560$ & $2,705,930$ & $6,563,700$ \\
\hline Global Competitiveness Report rankings ${ }^{1}$ & 48 & 74 & 60 \\
\hline Technology index (technological readiness pillar) & 35 & 43 & 40 \\
\hline Public institution index (institutions pillar) & 56 & 102 & 101 \\
\hline $\begin{array}{l}\text { Macroeconomic environment index } \\
\text { (macroeconomic environment pillar) }\end{array}$ & 40 & 60 & 46 \\
\hline $\begin{array}{l}\text { Business competitiveness index (business } \\
\text { sophistication pillar) }\end{array}$ & 41 & 82 & 96 \\
\hline \multicolumn{4}{|l|}{ European Innovation Scoreboard 5} \\
\hline Summary innovation index & 92.2 & 51.2 & 65.7 \\
\hline Human resources & 143.6 & 45.0 & 45.7 \\
\hline Attractive research systems & 90.2 & 37.2 & 58.4 \\
\hline Innovation-friendly environment & 87.7 & 40.6 & 88.1 \\
\hline Finance and support & 33.4 & 37.3 & 46.4 \\
\hline Firm investments & 121.0 & 96.7 & 78.3 \\
\hline Innovators & 95.6 & 72.1 & 17.6 \\
\hline Linkages & 112.3 & 66.5 & 69.5 \\
\hline Intellectual assets & 80.2 & 29.6 & 39.2 \\
\hline Employment impacts & 75.4 & 68.6 & 124.3 \\
\hline Sales impacts & 75.0 & 25.6 & 95.1 \\
\hline
\end{tabular}

Notes: ${ }^{1}$ GDP per capita (USD); total population; technology index; public institution index; macroeconomic environment; business competitiveness index (Schwab, 2017). ${ }^{2}$ Real GDP growth; consumer price inflation; unemployment rate; GDP per capita (PPP) (International Monetary Fund, 2018). ${ }^{3}$ Total labor force (The World Bank, 2017a). ${ }^{4}$ Population 15-64 (The World Bank, 2017b). ${ }^{5}$ European Innovation Scoreboard 2018 (European Commission, 2018); performance is measured relative to that of the EU in 2017.

Source: Author's systematization. 
Table 2 shows that according to the Global Competitiveness Report none of the countries can be considered as either technologically developed or globally competitive. According to the European summary innovation index, all three countries scored below the EU 2017 average. Slovenia is classified as a strong innovator (in a range between 90 percent and 120 percent of the EU average), with the human resources dimension being the strongest innovation dimension, while Croatia and Hungary are classified as moderate innovators. In Croatia the strongest innovation dimension is firm investment while in Hungary this is the employment impact.

\section{Results}

Logistic regression results for hypotheses $\mathrm{H} 1-\mathrm{H} 4$ are presented in Table 3. In this research, two alternative models (two blocks) are used to estimate the likelihood of an early-stage entrepreneur to perceive the innovativeness of products/services that he/she produces. Therefore, the dependent variable was innovativeness of products/services. Model A includes variables describing the technological innovativeness and innovativeness from the competitiveness viewpoint. Model $B$ additionally includes demographic variables, age, and gender, and it tests the significance of specific country effects on the product/service innovativeness, as well.

As we have anticipated, early-stage entrepreneurs who perceive their product/ service as an important novelty on the market are more likely to believe that this is related to their use of the latest technologies and processes not older than five years. This link is statistically significant; the results for Exp (B) in Model A show that those who perceive technological innovation in their businesses, on average, are almost twice as likely to develop or perceive innovation in the area of manufactured products or services, as compared to those who do not. A similar statistically significant relationship is also true regarding perceived competition and innovations: those who perceive lower levels of competition are almost four 
times more likely to develop or perceive innovation in the area of manufactured products, as compared to those who do not.

Table 3: Logistic Regression Results

\begin{tabular}{|c|c|c|c|c|c|c|c|}
\hline & \multicolumn{3}{|c|}{ Model A } & \multicolumn{3}{|c|}{ Model B } \\
\hline & & \multirow{2}{*}{$\begin{array}{l}\begin{array}{l}\text { Coefficient } \\
\text { (std. error) }\end{array} \\
\begin{array}{l}0.681^{* *} \\
(0.313)\end{array}\end{array}$} & \multirow{2}{*}{$\begin{array}{c}\text { Wald } \\
4.745\end{array}$} & \multirow{2}{*}{$\begin{array}{c}\operatorname{Exp}(\mathbf{B}) \\
1.976\end{array}$} & \multirow{2}{*}{$\begin{array}{l}\begin{array}{l}\text { Coefficient } \\
(\text { std. error })\end{array} \\
0.828^{* *} \\
(0.330)\end{array}$} & \multirow{2}{*}{$\begin{array}{c}\text { Wald } \\
6.298\end{array}$} & \multirow{2}{*}{$\begin{array}{c}\operatorname{Exp}(\mathbf{B}) \\
2.288\end{array}$} \\
\hline $\begin{array}{l}\text { Novelty of } \\
\text { technology } \\
\text { used }\end{array}$ & $\begin{array}{l}\text { No }=0 \\
\text { Yes }=1\end{array}$ & & & & & & \\
\hline $\begin{array}{l}\text { New to } \\
\text { customers }\end{array}$ & $\begin{array}{l}\mathrm{No}=0 \\
\mathrm{Yes}=1\end{array}$ & $\begin{array}{l}1.320^{* *} \\
(0.317)\end{array}$ & 17.333 & 3.734 & $\begin{array}{l}1.351^{* *} \\
(0.334)\end{array}$ & 16.393 & 3.861 \\
\hline Gender & $\begin{array}{c}\text { Men }=0 \\
\text { Women }=1\end{array}$ & & & & $\begin{array}{l}0.349 \\
(0.327)\end{array}$ & 1.134 & 1.417 \\
\hline Age & In years & & & & $\begin{array}{l}0.016 \\
(0.014)\end{array}$ & 1.212 & 1.016 \\
\hline \multirow{3}{*}{ Country } & Slovenia & & & & \multirow{3}{*}{\multicolumn{2}{|c|}{$\begin{array}{l}-0.047 \\
(0.391) \\
-0.556 \\
(0.397)\end{array}$}} & \\
\hline & Croatia & & & & & & 0.954 \\
\hline & Hungary & & & & & & 0.573 \\
\hline \multicolumn{8}{|l|}{ Model } \\
\hline Constant & & $\begin{array}{l}-3.002^{* *} \\
(0.292)\end{array}$ & 05.870 & & $\begin{array}{l}-3.934^{* *} \\
(0.864)\end{array}$ & 20.739 & \\
\hline $\begin{array}{l}\text { Model } \chi^{2}(d f) \\
\text { Block } \chi^{2}(d f)\end{array}$ & & \multicolumn{3}{|l|}{$25.134^{* *}(2)$} & \multicolumn{2}{|l|}{$\begin{array}{l}29.560^{* *}(6) \\
4.426(4)\end{array}$} & \\
\hline $\begin{array}{l}\text { Overall \% cor. } \\
\text { predictions }\end{array}$ & & \multicolumn{3}{|l|}{88.6} & \multicolumn{3}{|l|}{88.6} \\
\hline $\mathrm{R}^{2}$ (Nagelk.) & & \multicolumn{3}{|l|}{0.110} & \multicolumn{3}{|l|}{0.128} \\
\hline
\end{tabular}

Note: ${ }^{* *}$ denotes statistical significance at the 0.05 level.

Source: Author's calculations.

These identified relationships remain statistically significant and stable (and similar in strength) even after we include demographic variables and the country variable in the model. Thus, hypotheses $\mathrm{H} 1$ and $\mathrm{H} 2$ are confirmed. Higher innovativeness of products/services produced by early-stage entrepreneurs is associated with higher levels of technological innovativeness. Also, higher innovativeness of products/services produced by early-stage entrepreneurs is associated with lower levels of market competition. 
On the other hand, hypotheses $\mathrm{H} 3$ and $\mathrm{H} 4$ are not confirmed. Neither gender nor age shows a statistically significant relationship with the innovation of products/ services of early-stage entrepreneurs. Our research therefore expresses the view that women-owned/managed early-stage enterprises develop and produce new products and services that are perceived as an important novelty for all or most of their potential clients on a very similar scale as men-owned/managed ones. Hypothesis H3, which states that higher levels of innovativeness of products/ services produced are observed in male early-stage entrepreneurs as compared to female ones, is not confirmed. The same is true for age; hypothesis H4, which states that higher levels of innovativeness of products/services produced are observed in younger early-stage entrepreneurs as compared to older ones, is not confirmed.

In Model B, we also studied the country effects by including the country variables into the analysis. Countries were included using dummy variables, with 1 for each individual country and 0 otherwise. For indicator coding, Slovenia was the reference category. For all countries included in this part of the analysis, the country dummies were not significant $(\mathrm{p}>0.05)$.

\section{Discussion and Conclusion}

Innovation involves changing products, services, and work processes (Schumpeter, 1934). With the help of GEM data, we can determine whether early-stage entrepreneurs innovate in terms of introducing new products and/or services that customers perceive as new, in relation to the use of new technologies (process innovation), and with regard to the level of technological development of the industry in which they operate. As already emphasized, the limitation of the research is that early-stage entrepreneurs were assessing their perceptions regarding the three innovative aspects of their entrepreneurial endeavors-the actual state of innovativeness was not identified. Therefore, the results must be interpreted in light of the development of the national economy in question. The 
fact is that when the economy is more developed, the degree of perception of novelty of new products and/or services is lower.

The results show that the perceived novelty of technology used and of product/ service innovations are positively related, with technological innovativeness being related to an almost two times higher level of development of new products and services. This is a significant result that confirms how important it is for economic policy to enable the supporting environment for creating technological development, rather than imitating technologies from those who innovate. Although our research does not enable conclusions regarding the nature of technological novelty, it is very likely that innovative forms of entrepreneurial activity are based on digitalization and digital platforms. Various forms of innovative entrepreneurship are associated with digitalization, which co-creates an entrepreneurial ecosystem and is a prerequisite for the emergence of new alternative forms of entrepreneurship. At the same time, it also enables the creation of new types of services and new professions, such as "gig economy" (Burtch, Carnahan, \& Greenwood, 2018) or the provision of services on demand-business activities that are largely a consequence of the digitalization and use of different forms of digital platforms. The digital "gig economy" is also the special focus of the 2018 GEM research cycle, which will bring important insights in this research topic.

The results of the present research also show that perceived innovativeness regarding the competition that early-stage entrepreneurs face on the market, increases the likelihood of development of innovative, new products and services, almost fourfold. As previous research results suggest (Širec \& Močnik, 2016), analysis of the importance of competition for companies is a very comprehensive academic topic, but the findings are not uniform. While one of the views suggests that the effect of innovation on the existing market is relatively small (due to imitation and consequently a fall in profits), another view is that by creating or identifying new markets through innovation, one can establish a system of continuous creation of new demand. Our results show that innovative creation of 
new products and services, and innovativeness in comparison to competitors or lack of competition, are two factors that go hand in hand. Thus, it is reasonable to consider, in the framework of further research, the connection of these indicators with the internationalization levels of companies and with the analysis of active creation of new markets.

Our results also suggest that gender does not change the relationship between the innovativeness in terms of introducing new products and/or services and predictor variables; the relationship between the likelihood to perceive innovativeness in terms of introducing new products and/or services and innovativeness regarding technology and innovativeness regarding competition, does not depend on gender. In our sample, among those early-stage entrepreneurs who were introducing new products/services to the market, 30.1 percent were women and 69.9 percent were men. But our results suggest that, generally speaking, women's lower share is not due to differences between men and women, but due to some other factors, such as environmental and institutional factors, as Arenius and Minniti (2005) indicated when analyzing the likelihood of men and women to be a nascent entrepreneur. Similarly, stable results were found regarding age of entrepreneurs and across countries. These results also suggest that introducing the country effect into the model via the country dummy variables does not change the relationships of variables included into the model and the innovative product/service aspect of early-stage entrepreneurial activity. Thus, the specific institutional environment in each country does not moderate the relationships between the innovativeness of products/services on one hand, and technological and market competition viewpoints of innovativeness, on the other.

The innovation of early-stage companies and the stimulation of factors of their growth, especially in terms of job creation, is at the center of the attention of government programs in most economies. Because previous research results show that the studied phenomena are multifaceted and integrated into complex networking links, the findings of our research are important for policy makers, for entrepreneurs, and for academic research, as they add new insights into the 
research of this multidimensional innovation process and creation of an effective innovative entrepreneurial ecosystem.

We address the limitations of our study and possible directions for future research, as well. As already pointed out, the study is based on subjective measures of innovativeness where the problem of self-perception is present. The findings could be replicated using an objective measure of innovativeness that according to Koellinger (2008) needs to consider also the perception of customers or some performance criteria.

The logistic regression model could be further developed with additional control variables. The control variables may refer to the characteristics of entrepreneurs: fear of failure, opportunities recognition, self-confidence regarding entrepreneurial knowledge, skills and experience, etc., as well as to the characteristics of the institutional environment (Ardagna \& Lusardi, 2008; Aidis, Estrin, \& Mickiewicz, 2008; Estrin \& Mickiewics, 2011) and entrepreneurial ecosystem as a whole (Singer et al., 2017). This study utilized GEM data at the individual level for three selected countries. To present additional results, future research should encompass national level measurements in order to provide aggregate level distinctions and reasoning behind differences within regions and countries. Future research may also address the time dimension of the researched field, by pooling the GEM adult population survey data for more years into the pooled sample.

Acknowledgement: The author acknowledges the financial support from the Slovenian Research Agency (research core funding No. P5-0023). 


\section{Literature}

Acs, Z. J., Estrin, S., Mickiewicz, T., \& Szerb, L. (2018). Entrepreneurship, institutional economics and economic growth: An ecosystem perspective. Small Business Economics, 51(2), 501-514. doi: https://doi.org/10.1007/s11187-0180013-9

Aidis, R., Estrin, S., \& Mickiewicz, T. (2008). Institutions and entrepreneurship development in Russia: A comparative perspective. Journal of Business Venturing, 23, 656-672. doi: https://doi.org/10.1016/j.jbusvent.2008.01.005

Alsos, A. G., Isaksen, J. E., \& Ljunggren, E. (2006). New venture financing and subsequent business growth in men- and women-led businesses. Entrepreneurship Theory and Practice, 30(5), 667-686. doi: https://doi.org/10.1111/j.15406520.2006.00141.x

Ardagna, S., \& Lusardi, A. (2008). Explaining international differences in entrepreneurship: The role of individual characteristics and regulatory constraints. NBER Working Paper No. 14012. Retrieved from: http://citeseerx.ist.psu.edu/ viewdoc/download?doi=10.1.1.378.8678\&rep=rep1\&type=pdf.

Arenius, P., \& Minniti, M. (2005). Perceptual variables and nascent entrepreneurs. Small Business Economics, 24(3), 233-247. doi: https://doi.org/10.1007/s11187005-1984-x

Autio, E. (2007). Global Entrepreneurship Monitor 2007 global report on highgrowth entrepreneurship. London: London Business School and Babson Park, MA: Babson College.

Baum, R. J., Locke, A. E., \& Smith, G. K. (2001). A multidimensional model of venture growth. Academy of Management Journal, 44(2), 292-303. doi: https:// doi.org/10.5465/3069456

Baumol, W. J. (1993). Entrepreneurship, management and the structure of payoffs. Cambridge, MA: The MIT Press. 
Birch, D. L. (1979). The job generation process. Cambridge, MA: MIT Program on Neighborhood and Regional Change.

Brush, C., Carter, N., Gatewood, E., \& Hart, M. (2004). Clearing the hurdles: Women building high-growth business (First edition). Upper Saddle River, NJ: Financial Times Prentice Hall.

Burtch, G., Carnahan, S., \& Greenwood, B. N. (2018). Can you gig it? An empirical examination of the gig economy and entrepreneurial activity. Management Science, 64(12). doi: https://doi.org/10.1287/mnsc.2017.2916

Coad, A., \& Rao, R. (2008). Innovation and firm growth in high-tech sectors: A quantile regression approach. Research Policy, 37(4), 633-648. doi: https://doi. org/10.1016/j.respol.2008.01.003

Delmar, F., \& Holmquist, C. (2004). Women's entrepreneurship: Issues and policies. Proceedings of the 2nd OECD Conference of Ministers Responsible for SMEs: Promoting Entrepreneurship and Innovative SMEs in a Global Economy. Retrieved from: http://www.oecd.org/cfe/smes/31919215.pdf.

Estrin, S., \& Mickiewicz, T. (2011). Institutions and female entrepreneurship. Small Business Economics, 37(4), 397-415. doi: https://doi.org/10.1007/s11187011-9373-0

European Commission. (2018). European Innovation Scoreboard. Luxembourg: European Commission.

Falk, M. (2015). Employment effects of technological and organizational innovations: Evidence based on linked firm-level data for Austria. Jahrbücher für Nationalökonomie und Statistik, 235(3), 268-285. doi: https://doi.org/10.1515/ jbnst-2015-0303

Garcia, R., \& Calantone, R. (2002). A critical look at technological innovation typology and innovativeness terminology: A literature review. The Journal of Product Innovation Management, 19(2), 110-132. doi: https://doi.org/10.1016/ S0737-6782(01)00132-1 
GEM Manual. (2017). A report on the design, data and quality control of the Global Entrepreneurship Monitor. London: Global Entrepreneurship Research Association.

Global Entrepreneurship Research Association (GERA). (2018). Global Entrepreneurship Monitor: Globalreport 2017/18. London: Global Entrepreneurship Research Association.

Global Entrepreneurship Research Association (GERA). (2019). Global Entrepreneurship Monitor: 2018/2019 global report. London: Global Entrepreneurship Research Association.

Hullova, D., Trott, P., \& Simms, C. D. (2016). Uncovering the reciprocal complementarity between product and process innovation. Research Policy, 45(5), 929-940. doi: https://doi.org/10.1016/j.respol.2016.01.012

International Monetary Fund. (2018). World economic outlook (April 2018). Retrieved from http://www.imf.org/external/datamapper/datasets/WEO.

Klein, N. (2007). The shock doctrine: The rise of disaster capitalism. Toronto: Knopf Canada.

Koellinger, P. (2008). Why are some entrepreneurs more innovative than others? Small Business Economics, 31(1), 21-37. doi: https://doi.org/10.1007/s11187008-9107-0

Lafuente, E., Acs, Z., \& Szerb, L. (2018). The entrepreneurship paradox: More entrepreneurs are not always good for the economy - The role of the entrepreneurial ecosystem on economic performance in Africa. SSRN Working Paper Series. doi: https://doi.org/10.2139/ssrn.3307617

Morris, M., Webb, J., \& Bryant, R. F. (2011). Understanding the manifestation of entrepreneurial orientation in the nonprofit context. Entrepreneurship: Theory \& Practice, 35(5), 947-971. 
Neeley, L., \& Van Auken, H. (2010). Differences between female and male entrepreneurs' use of bootstrap financing. JournalofDevelopmentalEntrepreneurship, 15(1), 19-34. doi: https://doi.org/10.1142/S1084946710001439

Rebernik, M., Tominc, P., Crnogaj, K., Širec, K., Bradač Hojnik, B., \& Rus, M. (2016). Entrepreneurship between opportunity and necessity: GEM Slovenia 2015. Maribor: University of Maribor Press.

Rebernik, M., Tominc, P., Crnogaj, K., Bradač Hojnik, B., Rus, M., \& Širec, K. (2018). The growth of entrepreneurial aspirations. Maribor: University of Maribor Press.

Reynolds, P., Bosma, N., Autio, E., Hunt, S., De Bono, N., Servais, I., LopezGarcia, P., \& Chin, N. (2005). Global Entrepreneurship Monitor: Data collection design and implementation 1998-2003. Small Business Economics, 24(3), 205231. doi: https://doi.org/10.1007/s11187-005-1980-1

Romano, C. A., Tanewski, G. A., \& Smyrnios, K. X. (2001). Capital structure decision making: A model for family business. Journal of Business Venturing, 16(3), 285-310. doi: https://doi.org/10.1016/S0883-9026(99)00053-1

Roper, S., \& Scott, J. M. (2009). Perceived financial barriers and the start-up decision. International Small Business Journal, 27(2), 149-171. doi: https://doi. org/10.1177/0266242608100488

Schumpeter, J. (1934). The theory of economic development. Cambridge, MA: Harvard University Press.

Schwab, K. (Ed.). (2017). The global competitiveness report 2017-2018. Geneva: World Economic Forum. Retrieved from: https://www.weforum.org/reports/theglobal-competitiveness-report-2017-2018.

Singer, S., Šarlija, N., Pfeifer, S., \& Oberman Peterka, S. (2017). Gender patterns of businesses with growth potential in Croatia. In P. Wynarczyk \& M. Ranga (Eds.), Technology, commercialization and gender (pp. 101-140). Cham: Palgrave Macmillan. doi: https://doi.org/10.1007/978-3-319-49923-9_5 
Šarlija, N., \& Pfeifer, S. (2015). Differences in innovative orientation of the entrepreneurially active adults: The case of Croatia. International Journal of Social, Behavioral, Educational, Economic, Business and Industrial Engineering, 9(4), 1268-1275.

Širec, K., \& Močnik, D. (2016). A gender perspective of Slovenian high-growth firms' profitability. International Journal of Entrepreneurship \& Small Business, 27(2/3), 247-261. doi: https://doi.org/10.1504/IJESB.2016.073986

Tabachnick, B. G., \& Fidell, L. S. (2013). Using multivariate statistics. Upper Saddle River, NJ: Pearson.

Teece, D. J. (2007). Explicating dynamic capabilities: The nature and microfoundations of (sustainable) enterprise performance. Strategic Management Journal, 28(13), 1319-1350. doi: https://doi.org/10.1002/smj.640

The World Bank. (2017a). Labor force participation rate, total (\% of total population ages 15+) (modeled ILO estimate). Retrieved from https://data.worldbank.org/ indicator/SL.TLF.CACT.ZS.

The World Bank. (2017b). Population ages 15-64, total. Retrieved from https:// data.worldbank.org/indicator/SP.POP.1564.TO.

Tominc, P., \& Rebernik, M. (2006). Female entrepreneurial growth aspirations in Slovenia: An unexploited resource. In C. G. Brush, M. N. Carter, J. E. Gatewood, G. P. Greene, \& M. M. Hart (Eds.). Growth-oriented women entrepreneurs and their businesses: A global research perspective (pp. 330-348). Cheltenham and Northampton, MA: Edgar Elgar.

Zimmermann, V. (2009). The impact of innovation on employment in small and medium enterprises with different growth rates. Jahrbücher für Nationalökonomie und Statistik, 229(2-3), 313-326. doi: https://doi.org/10.1515/9783110508284013

Zimmermann, V. (2017). Success factors of high-growth enterprises. KfW Research: Focus on Economics No. 177. 